Article

\title{
Label-Free DNA Biosensor Using Modified Reduced Graphene Oxide Platform as a DNA Methylation Assay
}

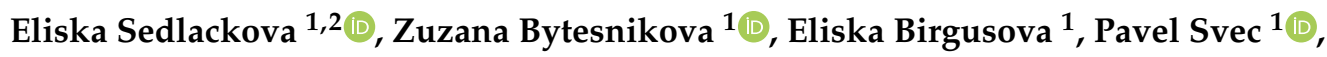 \\ Amir M. Ashrafi ${ }^{1}$ (D), Pedro Estrela ${ }^{3}$ (D) and Lukas Richtera ${ }^{1,2, *(D)}$ \\ 1 Department of Chemistry and Biochemistry, Mendel University in Brno, Zemedelska 1665/1, 61300 Brno, \\ Czech Republic; eliska.sedlackova@mendelu.cz (E.S.); zuzka.bytesnikova@gmail.com (Z.B.); \\ xbirguso@node.mendelu.cz (E.B.); svecpavel@centrum.cz (P.S.); amirmansoor.ashrafi@gmail.com (A.M.A.) \\ 2 Central European Institute of Technology, Brno University of Technology, Purkynova 123, 61200 Brno, \\ Czech Republic \\ 3 Centre for Biosensors, Bioelectronics and Biodevices (C3Bio) and Department of Electronic and Electrical \\ Engineering, University of Bath, Bath BA2 7AY, UK; p.estrela@bath.ac.uk \\ * Correspondence: richtera@mendelu.cz
}

Received: 14 October 2020; Accepted: 30 October 2020; Published: 3 November 2020

\begin{abstract}
This work reports the use of modified reduced graphene oxide (rGO) as a platform for a label-free DNA-based electrochemical biosensor as a possible diagnostic tool for a DNA methylation assay. The biosensor sensitivity was enhanced by variously modified rGO. The rGO decorated with three nanoparticles (NPs) — gold (AuNPs), silver (AgNPs), and copper (CuNPs)—was implemented to increase the electrode surface area. Subsequently, the thiolated DNA probe (single-stranded DNA, ssDNA-1) was hybridized with the target DNA sequence (ssDNA-2). After the hybridization, the double-stranded DNA (dsDNA) was methylated by M.SssI methyltransferase (MTase) and then digested via a HpaII endonuclease specific site sequence of CpG (5'-CCGG-3') islands. For monitoring the MTase activity, differential pulse voltammetry (DPV) was used, whereas the best results were obtained by rGO-AuNPs. This assay is rapid, cost-effective, sensitive, selective, highly specific, and displays a low limit of detection (LOD) of $0.06 \mathrm{U} \cdot \mathrm{mL}^{-1}$. Lastly, this study was enriched with the real serum sample, where a $0.19 \mathrm{U} \cdot \mathrm{mL}^{-1}$ LOD was achieved. Moreover, the developed biosensor offers excellent potential in future applications in clinical diagnostics, as this approach can be used in the design of other biosensors.
\end{abstract}

Keywords: nanomaterials; electrochemical biosensor; DNA methylation; rGO; biomedical applications

\section{Introduction}

In the last decade, research has confirmed the crucial role of epigenetics in the origin of cancer, its progression, and treatment. Epigenetics play an important role in genetic expressions, which are not affected by changes in DNA sequences. The most significant epigenetic mechanisms are DNA methylation, histone modification, and gene silencing related to RNA. DNA methylation's essential functions in cells occur under physiological and pathological conditions [1]. DNA methylation is a heritable post-translational covalent modification of DNA catalyzed by DNA methyltransferase (MTase). The process of methylation includes DNA MTase as the carrier of the methyl $\left(-\mathrm{CH}_{3}\right)$ group from S-adenosyl-methionine (SAM), which is a donor to the carbon in the 5th cytosine position in the dinucleotide field of $\mathrm{CpG}$ islands. Afterwards, MTase binds the methyl group to carbon in the cytosine's 5th position to create 5-methylcytosine. The distribution of 5-methylcytosine in the genome is specific for each cell type and is established during embryonic development. Nonetheless, the methylation 
of DNA is not stable; it may be enhanced by de novo methylation in the cells [2,3]. Compared to normal cells, tumor cells have a disrupted DNA methylation pattern, either reduced (hypomethylation) or increased (hypermethylation) by the number of methyl groups. Hypomethylation usually refers to repetitive DNA sequences, such as long scattered core elements, while hypermethylation refers only to $\mathrm{CpG}$ islands. Unfortunately, the mechanism of de novo methylation in normal and tumor cells is not well-understood [4]. The accumulation of DNA methylation changes can occur within a few years before the onset of malignant growth, so these changes could potentially be used in the early diagnosis of cancer [5]. Several methods suitable for DNA methylation determination, such as polymerase chain reaction (PCR), electrochemiluminescence, high-performance liquid chromatography, fluorescence, and colorimetric methods are widely used. These methods are highly effective; however, they have some drawbacks, including expensive instrumentation with a need for a considerable volume of samples, false-positive results, several washing steps, multiple-step samples preparation procedures, and skilled operators [6]. By contrast, biosensors are generally sensitive devices that convert a particular physical or chemical signal through a transducer into a more measurable signal and contain the recognition element composed of biological material (bioreceptor). Biosensors do not require skilled operators, expensive instrumentation, or multiple-step procedures of sample preparation. DNA biosensors, where DNA acts as a bioreceptor, are based on hybridization to a complementary DNA sequence. These biosensors are composed of an immobilized single-stranded DNA (ssDNA) to detect a complementary DNA sequence through hybridization. This leads to the formation of double-stranded DNA (dsDNA). DNA bioreceptors are simple, inexpensive, and widely used to detect DNA methylation [7]. Nevertheless, the development of innovative DNA-based biosensor strategies are highly desirable due to their sensitivity, low limit of detection, cost-effectiveness and specific analysis [8,9]. Unfortunately, in biosensor technology some obstacles must be overcome and improved, such as their stability and their implementation into integrated microfluidic devices [10].

Graphene oxide (GO) is commonly used in many scientific areas and disciplines due to its remarkable features. The specific surface with a large area and oxygen-rich functional groups supports thiolated DNA immobilization, excellent electrical conductivity, and cost-effective synthesis, which makes GO attractive for various electrochemical applications [11]. Reduction of GO is necessary for electrochemistry because the removal of oxygen-rich functional groups reinstates the $\pi$-conjugated system and thereby essential conductivity. The reduction of $\mathrm{GO}$ by $\mathrm{Na}\left[\mathrm{BH}_{4}\right]$ is strong, effective, and results in a similar C/O ratio as reduction by hydrazine [12]. Moreover, GO is widely used in biosensors fabrication due to the unique properties, such as the ratio of its surface area to volume, which ultimately makes the nanomaterial highly sensitive. Nevertheless, $\mathrm{Na}[\mathrm{BH} 4]$ reduction creates a material with smaller sheet resistance, making it more convenient for electrochemical applications [13]. The most important is nanoparticles' ability to conduct the electrical current, which depends on their distribution on reduced graphene oxide (rGO). Moreover, rGO has excellent thermal and electrical conductivity, large surface area, and additionally exhibit flexible and inert properties. rGO shows significantly reduced nanotoxicity compared to graphene and GO, which allows its wide use in biotechnological and biomedical applications. Among others, metal nanoparticles (NPs) can provide the highest electrical conductivity. The integration of different nanomaterials in the form of a composite has attracted biosensing attention as it can bring about the synergic effect of nanomaterials. Moreover, using this nanomaterial can increase the sensitivity and stability of this assay. Therefore, the nanocomposites, including rGO-silver NPs (AuNPs), rGO-gold NPs (AgNPs), and rGO-copper NPs (CuNPs), were synthesized and employed in a biosensor effect investigation on its analytical figures of merit [14].

In this study, the effect of three different nanocomposites rGO-AuNPs, rGO-AgNPs, rGO-CuNPs on the immobilization process's stability in signal enhancement was investigated. Many studies used only AuNPs [15,16] for biosensors development. Besides AuNPs, there exist other nanoparticles, such as AgNPs and CuNPs with quite high affinity to (-SH) suitable for biosensor fabrication as well. For instance, AgNPs are cheaper than gold, sufficiently stable, biocompatible, and can even prevent 
air oxidation [17]. On the other hand, CuNPs can be used as functional biological probes, and they can be quickly and easily prepared, with high deficiency, with almost no toxicity from a biological point of view and can also be intercalated into major DNA grooves [18]. The use of nanocomposites in biosensors fabrication has excellent potential. This is mainly due to the unique properties of used materials, which can replace conventional working electrodes (WEs) [19]. Moreover, the potential for these nanomaterials' production exists in almost every laboratory, which is very desirable in producing lab-on-chips or biochips, which are expected to be used in a future extension of the proposed study.

\section{Materials and Methods}

\subsection{Reagents}

Reagents in this publication acquired from Sigma-Aldrich (St. Louis, MO, USA) were of analytical grade or better quality unless otherwise stated. The specific synthetics sequences of DNA oligonucleotides and enzymes used in this study were adapted from [20]. Other chemicals used in this work, including methylene blue (MB), 1-mercapto-6-hexanol (MCH), chemicals for buffers preparation: sodium chloride $(\mathrm{NaCl})$, magnesium chloride $\left(\mathrm{MgCl}_{2}\right)$, Trizma ${ }^{\circledR}$ base, hydrochloric acid $\mathrm{HCl}(37 \%)$, sodium hydroxide $(\mathrm{NaOH})$, potassium sulfate $\left(\mathrm{K}_{2} \mathrm{SO}_{4}\right)$, potassium hexacyanoferrate $(\mathrm{III})\left(\mathrm{K}_{3}\left[\mathrm{Fe}(\mathrm{CN})_{6}\right]\right)$, potassium hexacyanoferrate(II) $\left(\mathrm{K}_{4}\left[\mathrm{Fe}(\mathrm{CN})_{6}\right]\right)$, sodium dihydrogen phosphate $\left(\mathrm{NaH}_{2} \mathrm{PO}_{4}\right)$ and sodium phosphate dibasic $\left(\mathrm{Na}_{2} \mathrm{HPO}_{4}\right)$. Reagents for the synthesis of GO and rGO-AuNPs: $0.24 \mathrm{mM}$ tetrachloroauric acid $\left(\mathrm{H}\left[\mathrm{AuCl}_{4}\right]\right), 37 \% \mathrm{HCl}, 0.085 \mathrm{M}$ sodium citrate $\left(\mathrm{Na}_{3} \mathrm{C}_{6} \mathrm{H}_{5} \mathrm{O}_{7}\right), 5 \%$ sodium carbonate $\left(\mathrm{Na}_{2} \mathrm{CO}_{3}\right)$, potassium permanganate $\left(\mathrm{KMnO}_{4}\right)$, sodium tetrahydridoborate $\left(\mathrm{Na}\left[\mathrm{BH}_{4}\right]\right)$ and hydrogen peroxide $\left(\mathrm{H}_{2} \mathrm{O}_{2}\right)$. Reagents for the of rGO-AgNPs: $10 \mathrm{mM}$ solution of silver nitrate $\left(\mathrm{AgNO}_{3}\right)$ and $\mathrm{Na}\left[\mathrm{BH}_{4}\right]$. Reagents for synthesizing rGO-CuNPs synthesis: copper acetate $\mathrm{Cu}\left(\mathrm{CH}_{3} \mathrm{COO}\right)_{2}$ and $\mathrm{Na}\left[\mathrm{BH}_{4}\right]$. Moreover, this study is enriched by real human sera samples (ERM ${ }^{\circledR}$ Certified Reference Material, St. Louis, MO, USA). All experiments used ultrapure Milli-Q (Millipore System Inc., Billerica, MA, USA) water with the corresponding resistivity of $18.2 \mathrm{M} \Omega \cdot \mathrm{cm}$.

\subsection{Apparatus}

\subsubsection{Physical and Chemical Characterization}

\section{Scanning Electron Microscopy (SEM)}

The sample was applied on a silica wafer and dried at ambient temperature $\left(24^{\circ} \mathrm{C}\right)$. This wafer was adhered to by a carbon tape to the stub, which was inserted into the scanning electron microscope (SEM). In this study, the SEM TESCAN MAIA 3 device (TESCAN Ltd., Brno, Czech Republic) coupled with a field-emission electron gun (TESCAN Ltd., Brno, Czech Republic) to investigate the composition and morphology of used nanocomposites. The method was adapted from a previous study [21] with slight modifications.

\section{SEM-Energy Dispersive X-ray Spectroscopy (EDX)}

In the study, SEM-energy dispersive X-ray spectroscopy (EDX) elemental mapping was performed for the determination of selected elements, such as $\mathrm{C}, \mathrm{O}, \mathrm{Au}, \mathrm{Ag}$ and $\mathrm{Cu}$, processed by $\mathrm{C} \mathrm{K} \alpha 1$ and 2; $\mathrm{O} \mathrm{K} \alpha 1, \mathrm{Ag} \mathrm{L} \alpha 1, \mathrm{Cu} \mathrm{L} \alpha 1$ and 2, and $\mathrm{Au} \mathrm{M} \alpha 1$ edges, respectively. As a measuring device MIRA 2 SEM (TESCAN Ltd., Brno, Czech Republic) coupled with an EDX detector X-MAX 50 (Oxford instruments plc, Abingdon, UK) was used and the images were evaluated by software AZtec (Oxford Instruments, Abingdon, UK). An external detector SE (Everhart-Thornley, TESCAN Ltd. Brno, Czech Republic) was selected for image processing with an accelerating voltage $15 \mathrm{kV}$. EDX mappings of selected elements, such as $\mathrm{C}, \mathrm{O}, \mathrm{Au}, \mathrm{Ag}$ and $\mathrm{Cu}$ were processed using $\mathrm{C} \mathrm{K} \alpha 1$ and 2; $\mathrm{O} \mathrm{K} \alpha 1, \mathrm{Ag} \mathrm{L} \alpha 1, \mathrm{Cu} \mathrm{L} \alpha 1$ and 2, and $\mathrm{Au} \mathrm{M} \alpha 1$ edges, respectively. Parameters of measurements were the following: working distance $15.4 \mathrm{~mm}$, input energy $20,000 \mathrm{cts}$, output energy $16,000 \mathrm{cts}$ with fluctuated dead time around $18-20 \%$. Each analysis took place in $20 \mathrm{~min}$. 


\subsubsection{Electrochemical Characterization}

Electrochemical studies, including electrochemical impedance spectroscopy (EIS) and differential pulse voltammetry (DPV) were performed in a standard three-electrode cell, with an $\mathrm{Ag} / \mathrm{AgCl}$ reference electrode linked by a salt bridge $\left(50 \mathrm{mM} \mathrm{PB}+0.1 \mathrm{M} \mathrm{K}_{2} \mathrm{SO}_{4}\right)$ at constant potential and with $\mathrm{Pt}$ auxiliary electrode. A gold electrode with radius of gold disk $1.6 \mathrm{~mm}\left(\mathrm{BASi}^{\circledR}\right.$, West Lafayette, IN, USA) was selected as working electrode (WE). An Autolab PGSTAT302N, in combination with a FRA2 potentiostat module (Metrohm, Herisau, Switzerland), was used for taking the electrochemical measurement.

\subsection{Methods}

\subsubsection{Synthesis and Reduction of Graphene Oxide (GO)}

GO was prepared by the well-established and optimized Hummer's method with slight modification [22].

The $\mathrm{pH}$ value of $\mathrm{GO}$ was adjusted to the value $9-10$ by the addition of $\mathrm{Na}_{2} \mathrm{CO}_{3}$. The mixture was heated up to $80^{\circ} \mathrm{C}$ and afterwards to it was added $800 \mathrm{mg}$ of $\mathrm{Na}\left[\mathrm{BH}_{4}\right]$, which is a strong reducing reagent. The temperature was maintained at $80^{\circ} \mathrm{C}$ for $1 \mathrm{~h}$. Finally, rGO was collected and rinsed three times with Milli-Q water [23].

\subsubsection{Synthesis of Nanocomposites}

Synthesis of Reduced GO (rGO)-Silver Nanoparticles (AgNPs) and rGO-Copper Nanoparticles (CuNPs)

A volume of $1 \mathrm{~mL}$ of $\mathrm{rGO}$ solution $\left(5 \mathrm{mg} \cdot \mathrm{mL}^{-1}\right)$ was added dropwise to the $\mathrm{AgNO}_{3}$ solution and vigorously stirred at $400 \mathrm{rpm}$. Then, $40 \mathrm{mg}$ of $\mathrm{Na}[\mathrm{BH} 4]$ was slowly added to the mixture, and the final solution was stirred for $24 \mathrm{~h}$ to complete reduction. The final nanocomposite was rinsed three times with Milli-Q water, and the final volume was adjusted to $10 \mathrm{~mL}$. For rGO-CuNPs synthesis, the $\mathrm{AgNO}_{3}$ was only replaced with $\mathrm{Cu}\left(\mathrm{CH}_{3} \mathrm{COO}\right)_{2}$.

Synthesis of rGO-Gold Nanoparticles (AuNPs)

An amount of $3.75 \mathrm{mg}$ of $\mathrm{rGO}$ was added to $50 \mathrm{~mL} \mathrm{H}\left[\mathrm{AuCl}_{4}\right]$, and the mixture was sonicated for $30 \mathrm{~min}$. Subsequently, the mixture was heated up to $80^{\circ} \mathrm{C}$ (stirred at $400 \mathrm{rpm}$ ), and $940 \mu \mathrm{L}$ of $\mathrm{Na}_{3} \mathrm{C}_{6} \mathrm{H}_{5} \mathrm{O}_{7}$ solution was added drop by drop. The solution was sustained at $80^{\circ} \mathrm{C}$ for $1 \mathrm{~h}$ and then cooled down to room temperature [24].

\subsubsection{Working Electrode (WE) Preparation}

Following the procedure of Keighley et al. [25] the WEs were cleaned and polished with a slight modification. WEs were firstly sonicated in absolute ethanol and then polished with diamond suspension $(0.5 \mu \mathrm{m})$ (Nanoshel LLC, Wilmington, DE, USA). Furthermore, a Piranha solution was prepared $\left(75 \% \mathrm{H}_{2} \mathrm{SO}_{4}: 25 \% \mathrm{H}_{2} \mathrm{O}_{2}\right.$, equals $3: 1$ volume), where the electrodes were rinsed to remove all the organic impurities. After mechanical and chemical cleaning, WEs were cleaned electrochemically via cyclic voltammetry $(\mathrm{CV})$ in $0.5 \mathrm{M} \mathrm{H}_{2} \mathrm{SO}_{4}$ by potential scanning between the gold reduction and oxidation vs. reference electrode $\mathrm{Ag} / \mathrm{AgCl}$ for 50 cycles until the voltammogram was established. After that, the WEs were rinsed with Milli-Q water, dried in argon steam (argon 5.0, Messer Industries $\mathrm{GmbH}$, Bad Soden, Germany), then caped and were ready to use.

2.3.4. rGO Immobilization, Single-Stranded DNA (ssDNA-1) Immobilization, and Hybridization with ssDNA-2

In this step, WEs were prepared by dropping $5 \mu \mathrm{l}$ of the selected nanocomposite (rGO-AuNPs, rGO-AgNPs, and rGO-CuNPs) on the electrode surface. Afterwards, the electrodes were dried for 
30 min under an infrared heat lamp (Beurer IL35, Ulm, Germany) with a power consumption of $150 \mathrm{~W}$. Then, the WEs were incubated with a thiol-modified DNA probe, which has a great affinity to attach to the metal surface through the thiol bond with selected nanocomposites. A further step involved incubation with $\mathrm{MCH}$ solution overnight at $+4{ }^{\circ} \mathrm{C}$ while the self-assembled monolayer (S-adenosyl-methionine, SAM) was formed to block the non-specific binding, prevents clusters forming, and helps to anchor the target molecules. Prior to hybridization, we performed back-filling with $1 \mu \mathrm{M}$ MCH for $90 \mathrm{~min}$. After that, the ssDNA-1 was hybridized with ssDNA-2 in the hybridization buffer [25]. Moreover, the probe and target were incubated at $37^{\circ} \mathrm{C}$ in an oven for $1 \mathrm{~h}$ to provide full hybridization.

2.3.5. Double-Stranded DNA (dsDNA) Methylation Process and the Digestion of dsDNA by HpaII Endonuclease

The modified WEs with ssDNA-1/dsDNA-2/rGO-AuNPs; -CuNPs or -AgNPs was treated by various concentrations prepared from $1.6 \mu \mathrm{M}$ stock solution of M.SssI MTase $(5 ; 15 ; 25 ; 50 ; 100 ; 150$; 200; 300; 400; $500 \mathrm{U} \cdot \mathrm{mL}^{-1}$ New England Biolabs, Ipswich, MA, USA). The modified WEs were exposed to the M.SssI MTase solution for $2 \mathrm{~h}$ at $37^{\circ} \mathrm{C}$ in the oven to be methylated and then incubated in $20 \mathrm{mM} \mathrm{MB}$ solution for $30 \mathrm{~min}$ at ambient temperature. After the successful methylation of the dsDNA, the modified WEs (ssDNA-1/dsDNA-2/rGO-AuNPs; -CuNPs or -AgNPs/M.SssI) were immersed in $20 \mathrm{U} \cdot \mathrm{ml}^{-1} \mathrm{HpaII}$ in Tango buffer for $2 \mathrm{~h}$ at $37^{\circ} \mathrm{C}$ in the oven. Then, the WEs were rinsed thoroughly with ultrapure water.

The prepared bare and modified WEs were characterized by using EIS. The impedance spectra were recorded in the solution of $5 \mathrm{mM} \mathrm{K}_{4}\left[\mathrm{Fe}(\mathrm{CN})_{6}\right]+5 \mathrm{mM} \mathrm{K}_{3}\left[\mathrm{Fe}(\mathrm{CN})_{6}\right]$ in $100 \mathrm{mM} \mathrm{PB}+100 \mathrm{mM}$ $\mathrm{K}_{2} \mathrm{SO}_{4}$ at $\mathrm{pH}$ 7.0. EIS was performed between working and auxiliary electrodes with the following parameters: the frequency ranges from $100 \mathrm{kHz}$ to $100 \mathrm{mHz}$ with an amplitude of $10 \mathrm{mV}$ alternating current (a.c.) voltage and $250 \mathrm{mV}$ direct current (d.c.) without external bias vs. reference electrode responds to the formal potential of the redox couple.

\subsubsection{Monitoring of M.SssI Methyltransferase (MTase) Activity}

The activity of M.SssI MTase was monitored by differential pulse voltammetry (DPV). The potential was swept from $0.0 \mathrm{~V}$ to $-0.6 \mathrm{~V}$, the potential amplitude was $0.025 \mathrm{~V}$, and the scan-rate was calculated as $0.01 \mathrm{~V} \cdot \mathrm{s}^{-1}$. Moreover, $20 \mathrm{mM} \mathrm{MB}$ solution was used as an electrochemical probe to measure the quantity of $10 \mathrm{nM}$ target sequences. The modified WEs were incubated for $30 \mathrm{~min}$.

\section{Results and Discussion}

\subsection{Biosensor Fabrication}

Figure 1 presents a simple, label-free, reliable, sensitive, and specific electrochemical DNA biosensor as a DNA methylation assay. In this approach, we have compared three different nanocomposites rGO-AuNPs, rGO-AgNPs, rGO-CuNPs, and their effect on the stability of the immobilization process, and the signal enhancement was investigated. The probe containing thiol groups $(-\mathrm{SH})$ was attached to a layer from the nanomaterials, as mentioned above, by a covalent bond with sulfur. To ensure stability, $\mathrm{MCH}$ was used to create the SAM which prevents cluster forming and non-specific binding of DNA. Therefore, the SAM helps to improve the stability of DNA immobilization by proper DNA arrangement [26]. The changes in the electrochemical features of the interfacial electrode surface due to the modifications were characterized via EIS. The methylation assay is based on the DPV response, which is correlated to the amount of the intercalated MB. MB creates a positive charge, leading to electrostatic interactions with negatively charged phosphoric acid of DNA, which allows creating $\pi-\pi$ interactions. The transfer of electrons flow from an electrode to the MB, and the obtained signals indicate the quantity of methylated cytosine. 


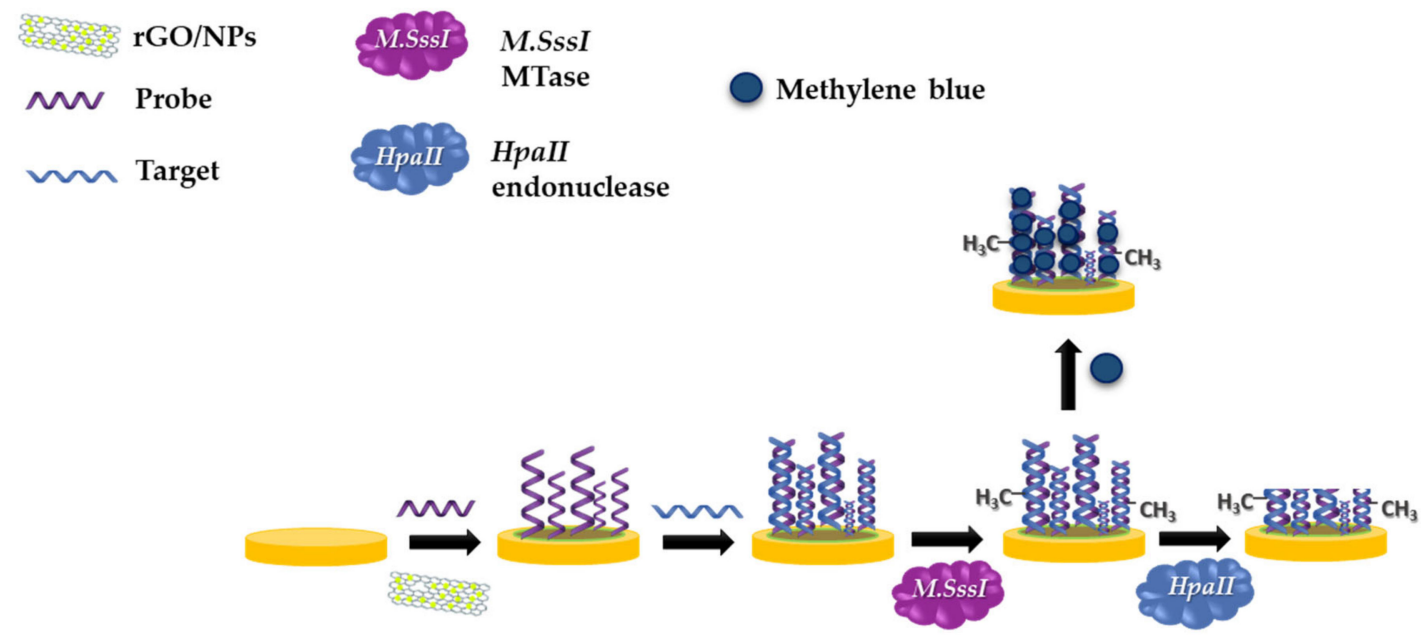

Figure 1. Schematic of biosensor development including each step of immobilization and treatment by enzymes.

\subsection{Scanning Electron Microscopy (SEM) Characterization of rGO Decorated with $A u, A g$ and $C u N P s$}

The images obtained from SEM (Figure 2) display the typical morphology of the specific nanomaterial and declare the presence of the desired carbon nanocomposites. GO synthetized by modified Hummer's method exhibited a uniform smooth microstructure with fine wrinkles. The reduction process of GO has resulted in a heavily wrinkled material with a preserved microstructure. Both materials exist in the form of large sheets. SEM images reveal the morphological characteristics of the prepared nanocomposites. In Figure 2A, it is evident that the layer of GO is visible and deeper wrinkles indicate the GO was also reduced (Figure 2B) during the synthesis of nanocomposites by $\mathrm{Na}\left[\mathrm{BH}_{4}\right]$.
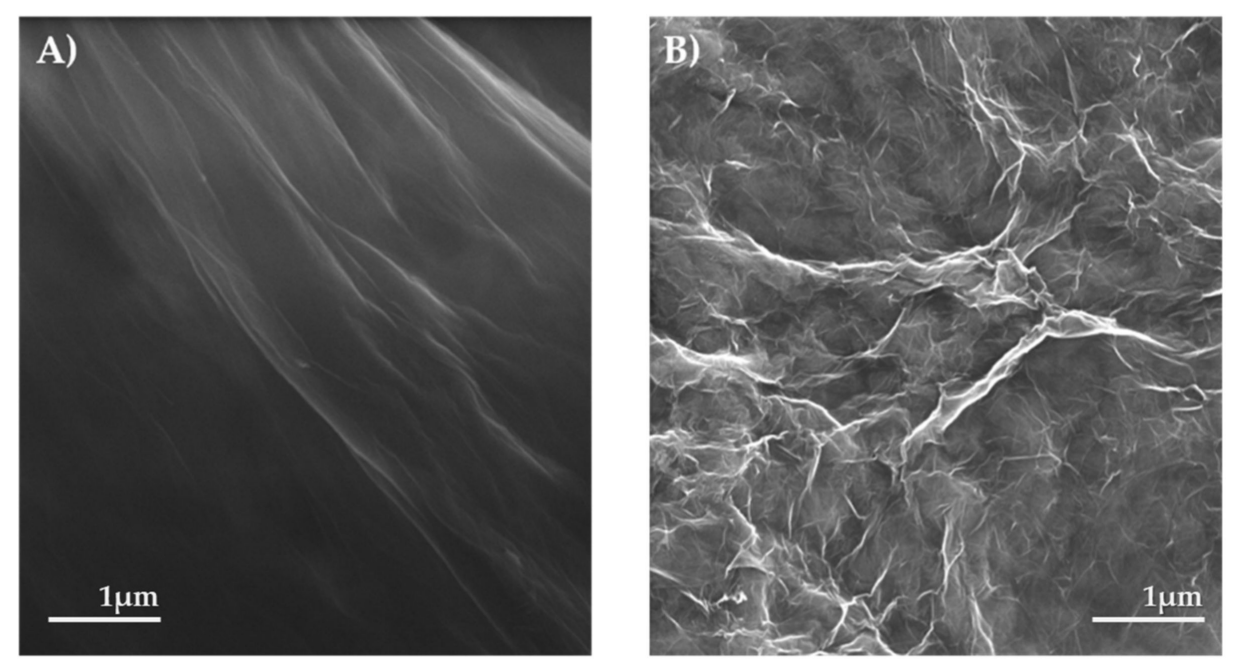

Figure 2. Images obtained from scanning electron microscope (SEM). (A) Graphene oxide (GO) and (B) reduced graphene oxide (rGO) with $1 \mu \mathrm{m}$ scale bar.

In all nanocomposites, NPs are consistently distributed on the surface of rGO, respectively. The AuNPs in Figure 3C are significantly smaller than AgNPs (A) and CuNPs (B), respectively, whereas all of the nanocomposites are shown in $1 \mu \mathrm{m}$ scale. AuNPs are distributed in nanometers. The diameter of AuNPs was 9-10 nm. On the other hand, the diameter of AgNPs was approximately $20 \mathrm{~nm}$ and the size of CuNPs was approximately 70-80 nm. SEM-EDX mapping image confirmed the occurrence of functional groups and the presence of expected elements that constitute NPs. All these 
nanocomposites were further characterized by FTIR technique, and obtained data are recorded in the Supplementary Materials (Figure S1).
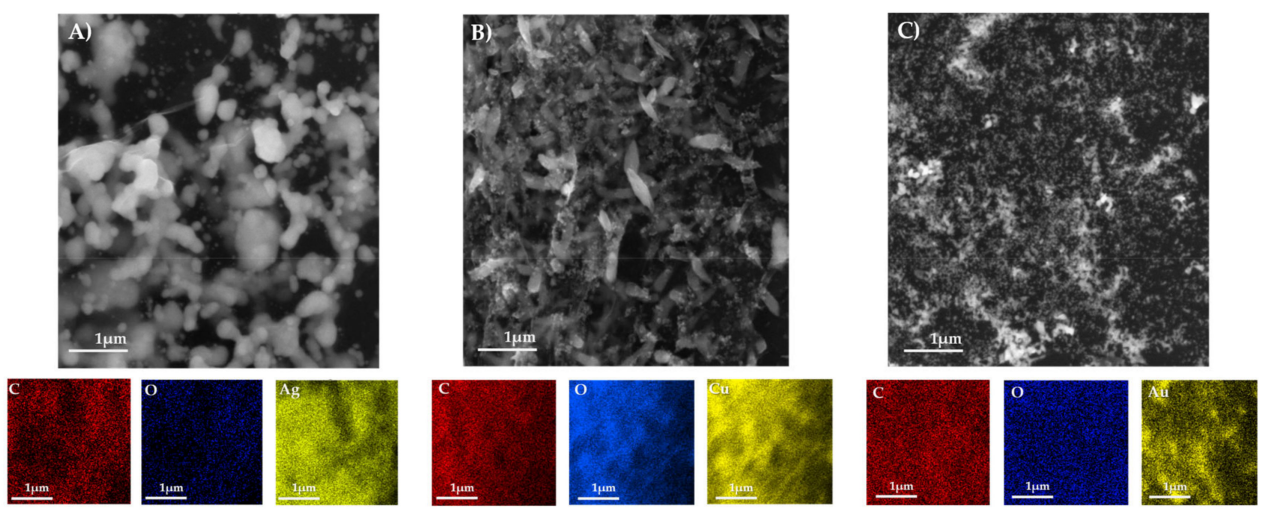

Figure 3. SEM images of nanocomposites of rGO decorated with the different metal nanoparticles. (A) silver nanoparticles (AgNPs), (B) copper nanoparticles (CuNPs), and (C) gold nanoparticles (AuNPs). Below are shown SEM-energy dispersive X-ray spectroscopy (EDX) images from the elemental mapping of demanded nanocomposites.

\subsection{Electrochemical Studies of Used Nanocomposites as Modification by Electrochemical Impedance Spectroscopy (EIS)}

EIS was used to characterize the successful modification and treatment of the WEs surface. As shown in Figure 4, the impedance spectra are composed of two parts, a semi-portion and a straight line. The semi-portion diameter is a demonstration of the charge transfer resistance, while the straight line represents the Warburg impedance, which is dominant at low frequencies due to diffusion processes [27]. Figure 4 shows the differences between each step of electrode surface modification for the three nanocomposites (rGO-AuNPs, rGO-AgNPs, and rGO-CuNPs). The bare working electrode has shown only a small semicircle signal in every record due to the free-electron transfer process. The equivalent circuit (Figure 4D) describing the system's behavior and the measured data are interpolated by the curve described by the equation corresponding to the stated circuit model.
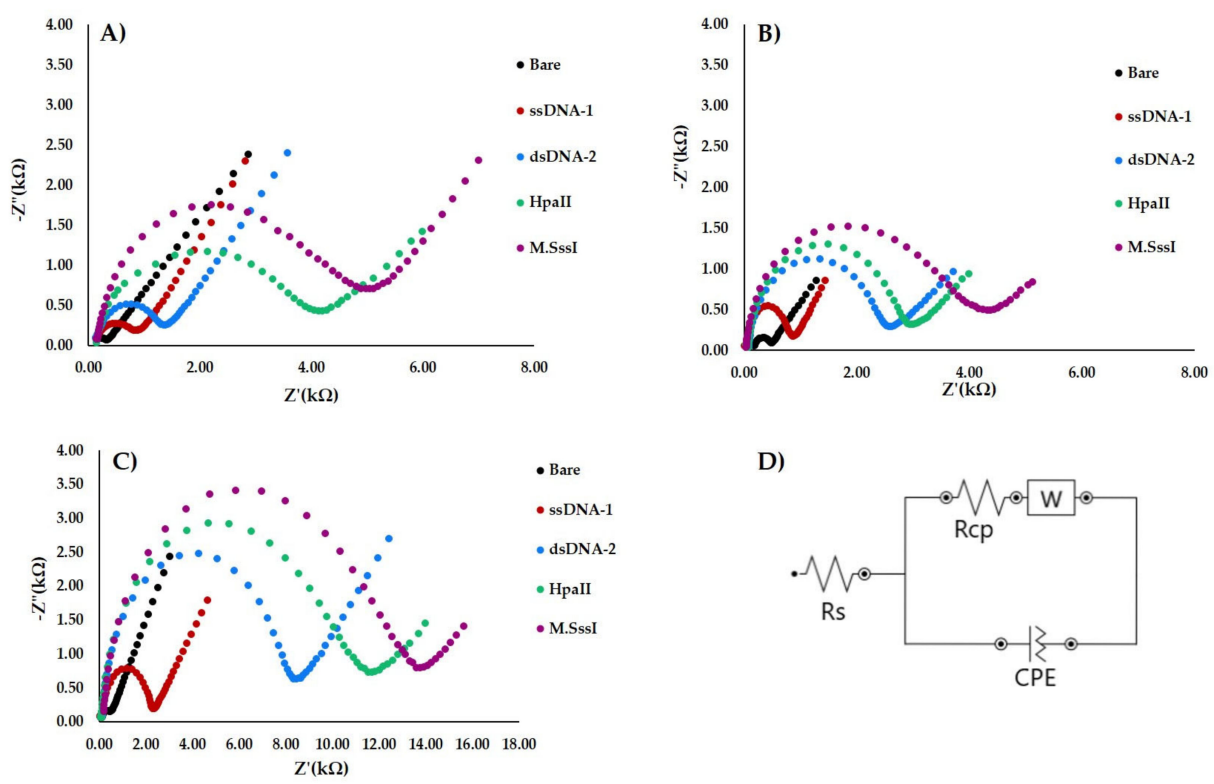

D)

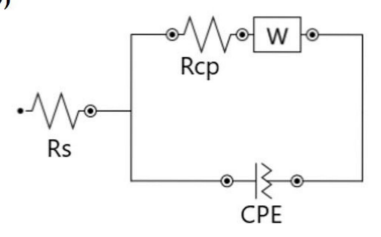

Figure 4. Electrochemical impedance spectroscopy (EIS) characterization of the electrodes prepared by different nanocomposites, where the Nyquist plot was recorded. (A) rGO-AgNPs, (B) rGO-CuNPs, (C) rGO-AuNPs and its (D) equivalent circuit. 
The immobilization of rGO-AuNPs with ssDNA-1 increased charge transfer resistance due to electron transfer from the electrode surface. The hybridization of ssDNA-1 with the target DNA further increased the charge transfer resistance. Considering that the utilized electrochemical $\left[\mathrm{Fe}(\mathrm{CN})_{6}\right]^{3-/ 4-}$ redox pair has a negative charge, the presence of DNA, which is also negatively charged, results in electrostatic repulsion. Hence, the increase of resistance in charge transfer directly after immobilization of the probe and the target DNA is understandable. After treating dsDNA with M.SssI Mtase that causes the methylation, the charge transfer resistance increased again. Increased steric hindrance can be caused by limiting the electrochemical probe's access to the electrode surface. The addition of HpaII causes dsDNA cleavage in a specific site, and consequently both the steric hindrance and the extent of the electrostatic repulsion decrease. Thus, the sensitivity of the developed biosensor depends on the difference in impedance magnitude in the process of probe immobilization and hybridization with target DNA where rGO-AuNPs show the highest difference because of better affinity -SH groups of ssDNA-1. In addition, modification with M. SssI and Hpall causes high impedance in rGO-AuNPs composite indicates better sensitivity.

\subsection{Monitoring of Methyltransferase Activity by Differential Pulse Voltammetry (DPV)}

As can be seen in Figure 5A, the peak height increases with concentration magnification of M. SssI Mtase concentration. This can be attributed to the higher amount of methylation on cytosine. Figure 5B shows the good linear correlation between the M.SssI concentration and peak current amplitude observed in a broad linear-dynamic range of 5-500 $\mathrm{U} \cdot \mathrm{mL}^{-1}$. For more reliable results there are displayed two calibration curves in Figure 5B. The equation for the M.SssI in concentration range $5-25 \mathrm{U} \cdot \mathrm{mL}^{-1}$ is: $I(\mu \mathrm{A})=0.0024 c\left(\mathrm{U} \cdot \mathrm{mL}^{-1}\right)+0.029$ with the correlation coefficient $\left(\mathrm{R}^{2}=0.9954\right)$. The lower limit of detection (LOD) was estimated to be $0.04 \mathrm{U} \cdot \mathrm{mL}^{-1}$, and the limit of quantification (LOQ) was $0.13 \mathrm{U} \cdot \mathrm{mL}^{-1}$, calculated based on $3 \sigma / k$ and $10 \sigma / k$, respectively. In this equation where $\sigma$ presents the relative standard deviation (RSD\%) obtained from three measurements of $500 \mathrm{U} \cdot \mathrm{mL}^{-1}$ concentration of M.SssI MTase and $k$ is the calibration curve slope. On the other hand, the remaining concentrations (50-500 U.mL $\mathrm{mL}^{-1}$ employ the equation: $I(\mu \mathrm{A})=0.0004 c\left(\mathrm{U} \cdot \mathrm{mL}^{-1}\right)+0.0984$ with the correlation coefficient $\left(R^{2}=0.99647\right)$. The LOD was calculated to be $0.06 \mathrm{U} \cdot \mathrm{mL}^{-1}$, and LOQ was $0.19 \mathrm{U} \cdot \mathrm{mL}^{-1}$. In the case of ssDNA-1/dsDNA-2/rGO-AgNPs the linear equation was $I(\mu \mathrm{A})=0.0004 c\left(\mathrm{U} \cdot \mathrm{mL}^{-1}\right)+0.0995$ with $\mathrm{R}^{2}=0.9698$. The same series of measurements was performed with ssDNA-1/dsDNA-2/rGO-CuNPs, where the equation of concentration dependence of the peak current was $I(\mu \mathrm{A})=0.0003 c\left(\mathrm{U} \cdot \mathrm{mL}^{-1}\right)$ $+0.0812\left(R^{2}=0.9895\right)$. Based on the results obtained, ssDNA-1/dsDNA-2/rGO-AuNPs shows better sensitivity in both EIS and DPV measurements.
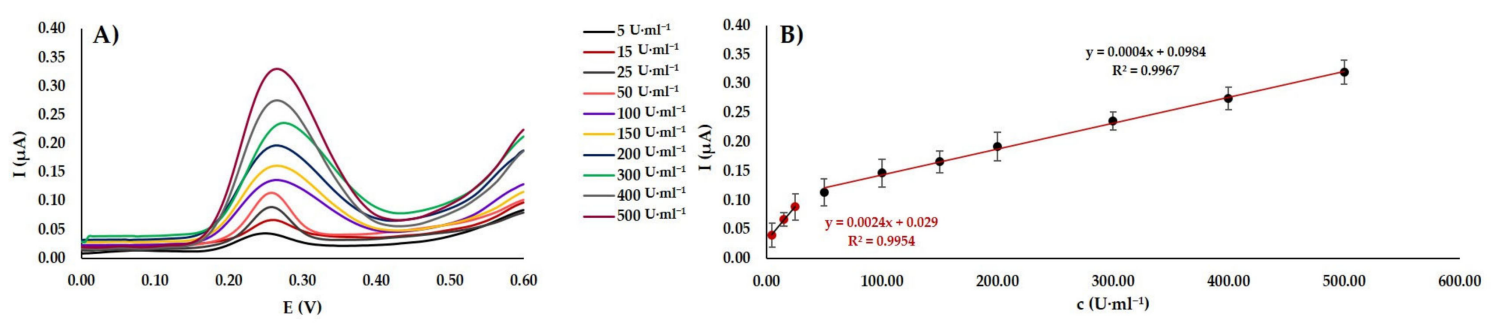

Figure 5. Monitoring of methyltransferase activity by differential pulse voltammetry (DPV). (A) The voltammograms of the modified WEs by ssDNA-1/dsDNA-2/rGO-AuNPs were then methylated by various concentrations of M.SssI Mtase. (B) The calibration curve showing the correlation between an electrochemical current response and concentration of M.SssI MTase. The error bars are represented using the relative standard deviation (RSD) of measurements $(n=3)$.

Nowadays, several studies aimed at a DNA methylation assay have been performed by many scientific groups. Table 1 summarizes the nanocomposites platforms, target enzymes or labels and the LODs used in numerous scientific works. The table is also enriched with the results of our DNA methylation assay. 
Table 1. Various study comparison in dependence of limit of detection (LOD) and nanocomposite platform used in the case of DNA methylation assays.

\begin{tabular}{cccccc}
\hline Nanocomposite Platform & Target Enzyme/Label & Technique & $\begin{array}{c}\text { Linear Range } \\
{\left[\mathbf{U} \cdot \mathbf{m L}^{-\mathbf{1}}\right]}\end{array}$ & $\begin{array}{c}\text { LOD } \\
{\left[\mathbf{U} \cdot \mathbf{m L}^{-\mathbf{1}} \text { ] }\right.}\end{array}$ & Reference \\
\hline AuNPs electrodeposition & M.SssI MTase & DPV & $0.50-400$ & 0.04 & {$[20]$} \\
DNA-AuNPs & Dam MTase & DPV & $0.08-30$ & 0.20 & {$[28]$} \\
AuNPs electrodeposition & M.SssI MTase/FcA ${ }^{1}$ & DPV & $0.50-400$ & 0.10 & {$[29]$} \\
AuNPs electrodeposition & T.aqI MTase & DPV & $0.10-100$ & 0.03 & {$[30]$} \\
- & Dam MTase/MB & DPV & $0.10-50$ & 0.07 & {$[31]$} \\
AuNPs electrodeposition & M.SssI MTase/HRP-IgG ${ }^{2}$ & DPV & $0.05-80$ & 0.10 & {$[32]$} \\
- & Dam MTase/RuHex ${ }^{3}$ & DPV & $0.25-10$ & 0.18 & {$[33]$} \\
AuNPs electrodeposition & M.SssI MTase & DPV & $0.50-550$ & 0.05 & {$[34]$} \\
rGO-AuNPs & M.SssI MTase & DPV & $50-500$ & 0.06 & This work \\
\hline FcA-Ferrocenecarboxylic & acid; 2 HRP-IgG-Horseradishperoxidase linked to secondary antibody;
\end{tabular}

\subsection{Demonstration of DNA Methylation Effect in Physiological Sera Samples}

Commercial human serum samples were used for real sample analysis (Figure 6). The undiluted serum samples were injected with different concentrations of the M.SssI MTase (Figure 6A). Then, a fabricated biosensor was utilized for monitoring the DNA methylation. As shown in Figure $6 \mathrm{~B}$, linear correlation can be observed between the resulting peak current and the desired concentration $\left(I(\mu \mathrm{A})=0.002 c\left(\mathrm{U} \cdot \mathrm{mL}^{-1}\right)+0.0263, \mathrm{R}^{2}=0.9934\right)$ in a concentration range of the M.SssI from 5 to $25 \mathrm{U} \cdot \mathrm{mL}^{-1}$. The LOD for 50 to $500 \mathrm{U} \cdot \mathrm{mL}^{-1}$ concentration was calculated to be $0.04 \mathrm{U} \cdot \mathrm{mL}^{-1}$, and the LOQ was $0.14 \mathrm{U} \cdot \mathrm{mL}^{-1}$. In a $50-500 \mathrm{U} \cdot \mathrm{mL}^{-1}$ concentration range of the M.SssI was obtained calibration equitation $I(\mu \mathrm{A})=0.0003 c\left(\mathrm{U} \cdot \mathrm{mL}^{-1}\right)+0.082$ with $\mathrm{R}^{2}=0.9959$. The $\mathrm{LOD}$ was evaluated to be $0.07 \mathrm{U} \cdot \mathrm{mL}^{-1}$, and the LOQ was $0.21 \mathrm{U} \cdot \mathrm{mL}^{-1}$. The calculation was based on $3 \sigma / k$ where $\sigma$ presents the $\mathrm{RSD} \%$ of three measurements of the $500 \mathrm{U} \cdot \mathrm{mL}^{-1}$ same concentration M.SssI MTase, and $k$ is the slope of the calibration curve. The obtained results indicate the applicability of the developed biosensor in complex physiological matrices.
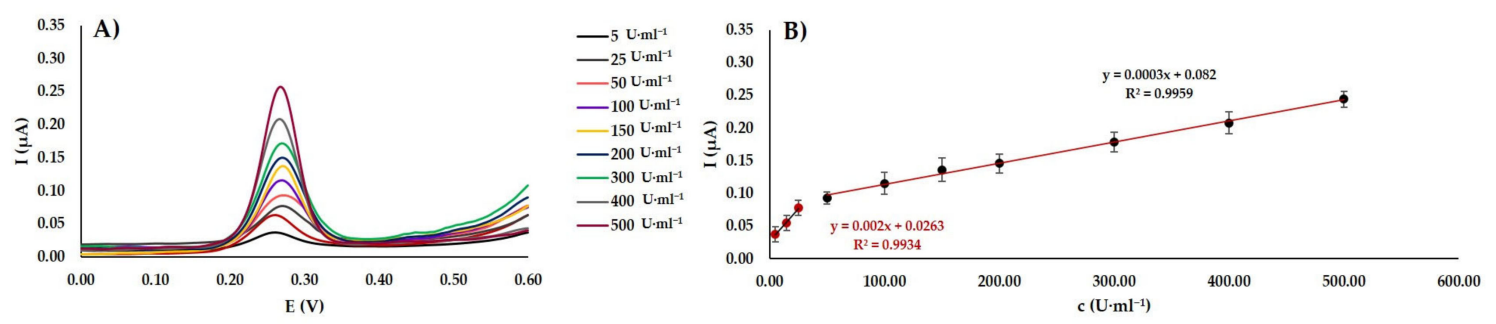

Figure 6. Analysis of methyltransferase activity by DPV in undiluted serum samples. (A) The voltammograms of the modified WEs by ssDNA-1/dsDNA-2/rGO-AuNPs were then methylated by various concentrations of M.SssI Mtase. (B) The calibration curve showing the correlation between an electrochemical current response and concentration of M.SssI MTase. The error bars are represented using the RSD\% of measurements $(n=3)$.

\subsection{Reproducibility, Repeatability and Stability Studies of the Fabricated Biosensor}

Reproducibility, stability, and selectivity studies are an important part of assay methods. The assay's repeatability was investigated by plotting three independent calibration curves by the same modified electrodes with rGO-AuNPs and calculating the RSD\% of the slopes. The calculated $\mathrm{RSD} \%=4.35$ shows good repeatability. This indicates that our approach can be used as an effective M.SssI MTase activity assay.

On the other hand, the biosensor's reproducibility was studied by analysis of a solution of $20 \mathrm{U} \cdot \mathrm{mL}^{-1}$ of HpaII with nine freshly prepared biosensors and then the RSD\% was calculated to be 4.78 
that confirms good reproducibility of the biosensor. This may stem from the stability of the complex between the rGO-AuNPs composite and the biological compounds.

As a last step the stability of the developed biosensor was investigated as well. The freshly fabricated biosensor was placed in the refrigerator for 7 days at $4{ }^{\circ} \mathrm{C}$ and applied for the analysis of the same concentration of DNA MTase, and $93.42 \%$ of the initial current response was obtained. This result has confirmed very good stability of the developed biosensor. The biosensor can be stored for a relatively long time without significantly affecting the accuracy of the measurement and it is capable of efficient and reliable analysis over time.

\section{Conclusions}

In conclusion, a simple, sensitive, and reliable electrochemical biosensor for methylated DNA determination and methyltransferase activity was developed. Three different nanocomposites, namely, rGO-AuNPs, rGO-AgNPs, rGO-CuNPs were synthesized, characterized, and applied in the sensor's construction. The best results in terms of sensitivity were obtained with rGO-AuNPs, which could be due to the high electrical conductivity of AuNPs. Furthermore, the AuNPs offer a good substrate for immobilization of the DNA, which further results in better stability and, consequently, sensitivity of the developed biosensor. This material was the most suitable for the DNA methylation assay due to the broad linear range of M.SssI concentration (50-500 U.mL $\left.{ }^{-1}\right)$. The biosensor developed with rGO-AuNPs showed good LOD $\left(0.06 \mathrm{U} \cdot \mathrm{mL}^{-1}\right)$ and LOQ $\left(0.19 \mathrm{U} \cdot \mathrm{mL}^{-1}\right)$. The LOD $\left(0.04 \mathrm{U} \cdot \mathrm{mL}^{-1}\right)$ and LOQ $\left(0.13 \mathrm{U} \cdot \mathrm{mL}^{-1}\right)$ values calculated from the M.SssI $\left(5-25 \mathrm{U} \cdot \mathrm{mL}^{-1}\right)$ concentration range indicate that very low concentrations can be reliably detected.

In comparison with other studies in Table 1, this material is appropriate for biosensor fabrication. In the case of analysis in human serum samples, it has been shown that even in the biological matrix, the biosensor can achieve $0.07 \mathrm{U} \cdot \mathrm{mL}^{-1} \mathrm{LOD}$ and LOQ of $0.21 \mathrm{U} \cdot \mathrm{mL}^{-1}$, which is almost identical to the use in analysis in a buffer. The validation of the developed biosensor confirmed its accuracy and precision. Therefore, the developed biosensor offers an alternative that can be utilized in clinical analysis for preliminary measurement.

Supplementary Materials: The following are available online at http://www.mdpi.com/1996-1944/13/21/4936/s1, Figure S1: Fourier transform infrared (FTIR) spectra of GO (black) and prepared nanocomposites: rGO (red), rGO-CuNPs (green), rGO-AuNPs (blue) and rGO-AgNPs (orange).

Author Contributions: P.E. conceptualized experiment and choose proper methodology; E.S. designed experiment, wrote the manuscript, provided measurement via electrochemistry and undertook formal analysis; P.E. conceptualized the experiment and chose the proper methodology; A.M.A. supervised the manuscript and processed data curation; E.B. processed data curation and some electrochemical experiments; Z.B. synthesized and provided nanocomposites; P.S. performed SEM analysis; L.R. supervised the manuscript and performed FTIR analysis. All authors have read and agreed to the published version of the manuscript.

Funding: This research was funded by IGA MENDELU, grant number AF-IGA2019-IP059 and was carried out under the project CEITEC 2020 (LQ1601) with financial support from the Ministry of Education, Youth and Sports of the Czech Republic under the National Sustainability Programme II.

Conflicts of Interest: The authors declare no conflict of interest. The funders had no role in the design of the study; in the collection, analyses, or interpretation of data; in the writing of the manuscript; or in the decision to publish the results.

\section{References}

1. Krejcova, L.; Richtera, L.; Hynek, D.; Labuda, J.; Adam, V. Current trends in electrochemical sensing and biosensing of DNA methylation. Biosens. Bioelectron. 2017, 97, 384-399. [CrossRef]

2. Yin, H.; Xu, Z.; Wang, M.; Zhang, X.; Ai, S. An electrochemical biosensor for assay of DNA methyltransferase activity and screening of inhibitor. Electrochim. Acta 2013, 89, 530-536. [CrossRef]

3. Chen, X.; Huang, J.; Zhang, S.; Mo, F.; Su, S.; Li, Y.; Fang, L.; Deng, J.; Huang, H.; Luo, Z.; et al. Electrochemical Biosensor for DNA Methylation Detection through Hybridization Chain-Amplified Reaction Coupled with a Tetrahedral DNA Nanostructure. ACS Appl. Mater. Interfaces 2019, 11, 3745-3752. [CrossRef] [PubMed] 
4. Zhu, B.; Booth, M.A.; Shepherd, P.; Sheppard, A.; Travas-Sejdic, J. Distinguishing cytosine methylation using electrochemical, label-free detection of DNA hybridization and ds-targets. Biosens. Bioelectron. 2015, 64, 74-80. [CrossRef] [PubMed]

5. Yin, H.; Yin, H.; Xu, Z.; Chen, L.; Zhang, D.; Ai, S. An electrochemical assay for DNA methylation, methyltransferase activity and inhibitor screening based on methyl binding domain protein. Biosens. Bioelectron. 2013, 41, 492-497. [CrossRef]

6. Chen, S.;Su, J.; Zhao, Z.; Shao, Y.; Dou, Y.; Li, F.; Deng, W.; Shi, J.; Li, Q.; Zuo, X.; et al. DNA framework-supported electrochemical analysis of DNA methylation for prostate cancers. Nano Lett. 2020, 20, 7028-7035. [CrossRef]

7. Zhang, Q.; Wu, Y.; Xu, Q.; Ma, F.; Zhang, C.-Y. Recent advances in biosensors for in vitro detection and in vivo imaging of DNA methylation. Biosens. Bioelectron. 2020, 112712. [CrossRef]

8. Huang, J.; Zhang, S.; Mo, F.; Su, S.; Chen, X.; Li, Y.; Fang, L.; Huang, H.; Deng, J.; Liu, H.; et al. An electrochemical DNA biosensor analytic technique for identifying DNA methylation specific sites and quantify DNA methylation level. Biosens. Bioelectron. 2019, 127, 155-160. [CrossRef]

9. Mascini, M.; Tombelli, S. Biosensors for biomarkers in medical diagnostics. Biomarkers 2008, 13, 637-657. [CrossRef]

10. Mehrotra, P. Biosensors and their applications-A review. J. Oral Biol. Craniofacial Res. 2016, 6, 153-159. [CrossRef]

11. Gao, L.; Lian, C.; Zhou, Y.; Yan, L.; Li, Q.; Zhang, C.; Chen, L.; Chen, K. Graphene oxide-DNA based sensors. Biosens. Bioelectron. 2014, 60, 22-29. [CrossRef]

12. Guex, L.G.; Sacchi, B.; Peuvot, K.F.; Andersson, R.L.; Pourrahimi, A.M.; Ström, V.; Farris, S.; Olsson, R.T. Experimental review: Chemical reduction of graphene oxide (GO) to reduced graphene oxide (rGO) by aqueous chemistry. Nanoscale 2017, 9, 9562-9571. [CrossRef] [PubMed]

13. Shin, H.; Kim, K.K.; Benayad, A.; Yoon, S.; Park, H.K.; Jung, I.; Jin, M.H.; Jeong, H.; Kim, J.M.; Choi, J.; et al. Efficient Reduction of Graphite Oxide by Sodium Borohydride and Its Effect on Electrical Conductance. Adv. Funct. Mater. 2009, 19, 1987-1992. [CrossRef]

14. Zhou, M.; Zhai, Y.; Dong, S. Electrochemical Sensing and Biosensing Platform Based on Chemically Reduced Graphene Oxide. Anal. Chem. 2009, 81, 5603-5613. [CrossRef]

15. Liu, P.; Wang, D.; Zhou, Y.; Wang, H.; Yin, H.; Ai, S. DNA methyltransferase detection based on digestion triggering the combination of poly adenine DNA with gold nanoparticles. Biosens. Bioelectron. 2016, 80, 74-78. [CrossRef] [PubMed]

16. Kokkinos, C. Electrochemical DNA Biosensors Based on Labeling with Nanoparticles. Nanomaterials 2019, 9, 1361. [CrossRef] [PubMed]

17. Qing, Z.; Bai, A.; Xing, S.; Zou, Z.; He, X.; Wang, K.; Yang, R. Progress in biosensor based on DNA-templated copper nanoparticles. Biosens. Bioelectron. 2019, 137, 96-109. [CrossRef]

18. Zhang, X.; Guo, Q.; Cui, D.-X. Recent Advances in Nanotechnology Applied to Biosensors. Sensors 2009, 9, 1033-1053. [CrossRef] [PubMed]

19. Bao, J.; Geng, X.; Hou, C.; Zhao, Y.; Huo, D.; Wang, Y.; Wang, Z.; Zeng, Y.; Yang, M.; Fa, H.-B. A simple and universal electrochemical assay for sensitive detection of DNA methylation, methyltransferase activity and screening of inhibitors. J. Electroanal. Chem. 2018, 814, 144-152. [CrossRef]

20. Jamróz, E.; Kopel, P.; Tkaczewska, J.; Dordević, D.; Jančíková, S.; Kulawik, P.; Milosavljevic, V.; Dolezelikova, K.; Smerkova, K.; Svec, P.; et al. Nanocomposite Furcellaran Films-The Influence of Nanofillers on Functional Properties of Furcellaran Films and Effect on Linseed Oil Preservation. Polymers 2019, 11, 2046. [CrossRef]

21. Besenhard, J.O. Preparation of Graphite Oxides. In Inorganic Reactions and Methods; Wiley-VCH Publishers: Weinheim, Germany, 1990; pp. 261-262.

22. Gao, W.; Alemany, L.B.; Ci, L.; Ajayan, P.M. New insights into the structure and reduction of graphite oxide. Nat. Chem. 2009, 1, 403-408. [CrossRef] [PubMed]

23. Goncalves, G.; Marques, P.A.A.P.; Granadeiro, C.M.; Nogueira, H.I.S.; Singh, M.K.; Graácio, J. Surface Modification of Graphene Nanosheets with Gold Nanoparticles: The Role of Oxygen Moieties at Graphene Surface on Gold Nucleation and Growth. Chem. Mater. 2009, 21, 4796-4802. [CrossRef]

24. Keighley, S.D.; Li, P.; Estrela, P.; Migliorato, P. Optimization of DNA immobilization on gold electrodes for label-free detection by electrochemical impedance spectroscopy. Biosens. Bioelectron. 2008, 23, 1291-1297. [CrossRef]

25. Bizzotto, D.; Burgess, I.J.; Doneux, T.; Sagara, T.; Yu, H.-Z. Beyond Simple Cartoons: Challenges in Characterizing Electrochemical Biosensor Interfaces. ACS Sensors 2018, 3, 5-12. [CrossRef] 
26. Macdonald, J.R.; Johnson, W.B. Fundamentals of Impedance Spectroscopy. Impedance Spectroscopy 2005, 1, 1-26. [CrossRef]

27. Jing, X.; Cao, X.; Wang, L.; Lan, T.; Li, Y.; Xie, G. DNA-AuNPs based signal amplification for highly sensitive detection of DNA methylation, methyltransferase activity and inhibitor screening. Biosens. Bioelectron. 2014, 58, 40-47. [CrossRef] [PubMed]

28. Liu, S.; Wu, P.; Li, W.; Zhang, H.; Cai, C. An electrochemical approach for detection of DNA methylation and assay of the methyltransferase activity. Chem. Commun. 2011, 47, 2844-2846. [CrossRef]

29. Xu, Z.; Wang, M.; Zhou, T.; Yin, H.; Ai, S. Electrochemical biosensing method for the detection of DNA methylation and assay of the methyltransferase activity. Sensors Actuators B Chem. 2013, 178, 412-417. [CrossRef]

30. Su, J.; He, X.; Wang, Y.; Zou, Z.; Chen, Z.; Yan, G. A sensitive signal-on assay for MTase activity based on methylation-responsive hairpin-capture DNA probe. Biosens. Bioelectron. 2012, 36, 123-128. [CrossRef]

31. Wang, M.; Xu, Z.; Chen, L.; Yin, H.; Ai, S. Electrochemical Immunosensing Platform for DNA Methyltransferase Activity Analysis and Inhibitor Screening. Anal. Chem. 2012, 84, 9072-9078. [CrossRef]

32. Wang, G.L.; Zhou, L.Y.; Luo, H.Q.; Li, N.B. Electrochemical strategy for sensing DNA methylation and DNA methyltransferase activity. Anal. Chim. Acta 2013, 768, 76-81. [CrossRef]

33. Li, W.; Wu, P.; Zhang, H.; Cai, C. Signal Amplification of Graphene Oxide Combining with Restriction Endonuclease for Site-Specific Determination of DNA Methylation and Assay of Methyltransferase Activity. Anal. Chem. 2012, 84, 7583-7590. [CrossRef]

34. Huang, B.; Ji, L.; Liang, B.; Cao, Q.; Tu, T.; Ye, X. A simple and low-cost screen printed electrode for hepatocellular carcinoma methylation detection. Analyst 2019, 144, 3282-3288. [CrossRef] [PubMed]

Publisher's Note: MDPI stays neutral with regard to jurisdictional claims in published maps and institutional affiliations. 